\title{
Usability Evaluation of Scientific Journal Websites using the System Usability Scale (Case Study of the OPSI Journal Website)
}

\author{
Sadi', Eko Nursubiyantoro², Yuli Dwi Astanti ${ }^{3}$, Ismianti ${ }^{4}$, Astrid Wahyu Adventri Wibowo5, \\ Hasan Mastrisiswadi ${ }^{6}$ \\ 1,2,3,4,5,6 Industrial Engineering Department, Universitas Pembangunan Nasional Veteran Yogyakarta, \\ Indonesia
}

\begin{abstract}
The government has initiated the accreditation of journals as publication media to improve the quality and quantity of research in Indonesia to have competitiveness against international publication media. As one of the scientific journals, the OPSI Journal has just received a Sinta 3 rating in journal accreditation. To improve the quality of the journal, it is necessary to evaluate the usability level of the OPSI Journal website so that the strategies that must be used in improving its quality can be identified. The usability level evaluation is carried out using the System Usability Scale (SUS), which has many advantages. The evaluation was carried out on users of the OPSI journal website categorized into four groups: reviewers, authors, editors, and readers. Based on the results of the research conducted, it was found that the highest usability value was in the author group, and the lowest was in the editor group.
\end{abstract}

Keywords: journal, usability, website, OPSI

This is an open access article under the CC-BY-NC license

\section{INTRODUCTION}

In development of journals as publication media, the government has initiated the accreditation of journals as publication media to improve the quality and quantity of research in Indonesia to have competitiveness against international publication media. The accreditation of this journal has been widely known as SINTA, where SINTA is divided into six categories, namely SINTA 1 to SINTA 6. Each category has a different value depending on the journal's quality, where the highest accreditation is in SINTA 1.

Currently, the OPSI Journal, a journal managed by the Department of Industrial Engineering, has just obtained SINTA 3 accreditation according to the Decree of the Minister of Research and Technology/Head of the National Research and Innovation Agency Number 200/M/KPT/2020. However, based on self-assessment, the OPSI Journal volunteered to get SINTA 2 accreditation. There are several shortcomings and weaknesses, especially on the journal's website, so that the accreditation target has not been fully met. For this reason, a study is needed to improve the quality of the OPSI Journal in its efforts to achieve better accreditation.

To improve the quality of the journal, one of the steps that can be taken is to evaluate the level of reusability. Knowing the usability level of the OPSI journal website shows what steps must be taken to improve and improve its quality.

\section{LITERATURE REVIEW}

In the Law on the National Education System number 20 of 2003 article 20 paragraph 2, it is stated that universities are obliged to carry out education, research, and community service. (Departemen Pendidikan Nasional, 2003). These three activities are better known as the Tridharma of Higher Education, which are interrelated. According to Lian, the Dharma of education and research must concretely support the dharma of community service (Lian, 2019). Thus, the task of lecturers is not only teaching but also research and community service. Teaching activities are carried out periodically and periodically, while research activities are carried out with evidence of Scientific Journals (Fathurrahman \& Muhtarom, 2019). 
As a publication media, the journal must improve its quality by improving its website. One way to evaluate a journal's website is to use its level of usefulness, which is better known as the System Usability Scale (SUS). The System Usability Scale (SUS) was developed by Brooke $(1996,2013)$. This method has been widely used to assess the level of usability of a system, product, and website (Brooke, 2013; Derisma, 2020; Kaya, Ozturk, \& Altin Gumussoy, 2019; Kharis, Santosa, \& Winarno, 2019; Pangestu, Safe'i, Darmawan, \& Kaskoyo, 2020; Ramadhan, 2019; Saputra, 2019a, 2019b; Sidik, 2018). SUS has several advantages so that it is widely used, including easy, simple, inexpensive, and does not require too many respondents (Brooke, 2013).

\section{RESEARCH METHOD}

\section{Research object}

The object of this research is the OPSI website which will be evaluated for its usability level. The OPSI website is a website that publishes scientific works, technological engineering research in the fields of Industrial Engineering, Industrial Systems, Industrial Management and Information Technology. This journal has been indexed by DOAJ and accredited Sinta 3 by the Ministry of Research and Technology/National Research and Innovation Agency.

\section{Data collection}

Data were collected using a System Usability Scale (SUS) questionnaire. Questionnaires were sent to authors, reviewers, editors, and readers via email and included on the Journal website. The SUS questionnaire itself consists of ten questions as follows (Brooke, 2013):

- I think that I would like to use this system frequently

- I found the system unnecessarily complex

- I thought the system was easy to use

- I think that I would need the support of a technical person to be able to use this system

- I found the various function in this system were well integrated

- I thought there was too much inconsistency inthis system

- I would imagine that most people would learn to use the system very quickly

- I found the system very cumbersome to use

- I felt very confident using the system

- I needed to learn a lot of things before I could get going with the system

\section{System Usability Scale (SUS)}

This method uses ten questions and is answered with a Likert scale. The results of this questionnaire will be converted into a value to assess whether a system is feasible or not (Brooke, 2013). In assessing the SUS score, several stages are carried out, namely:

- Statement of odd number instruments on the instrument answer scale minus 1

- The statement of the instrument is an even number, then 5 is reduced by the scale of the instrument's answer.

- The results of the assessment scale 0 - 4 (4 is the best answer).

- Doing the number of answers then multiplied by 2.5

- Determine the average value of the test instrument answers for all respondents The results of the average value of these answers are then compared with the SUS scale.

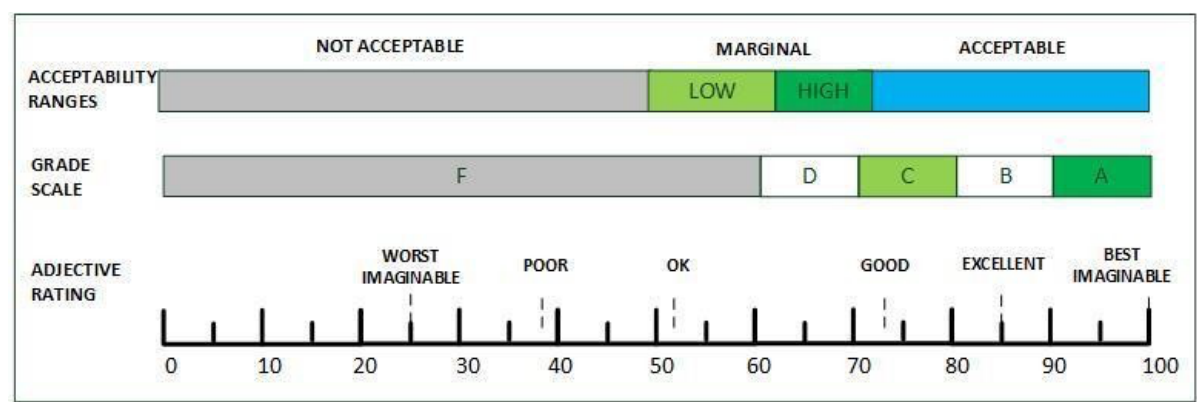

Figure 1. SUS (Brooke, 2013) 


\section{FINDING AND DISCUSSION}

\section{Respondent Group}

The first step in this research is to make a SUS questionnaire into a form and then distribute it to the respondents. The target respondents in this study were divided into four groups, namely reviewers, editors, authors, and readers. Based on the results of the questionnaire distribution, the composition of the data of respondents who filled out the questionnaire can be seen in Figure 2.

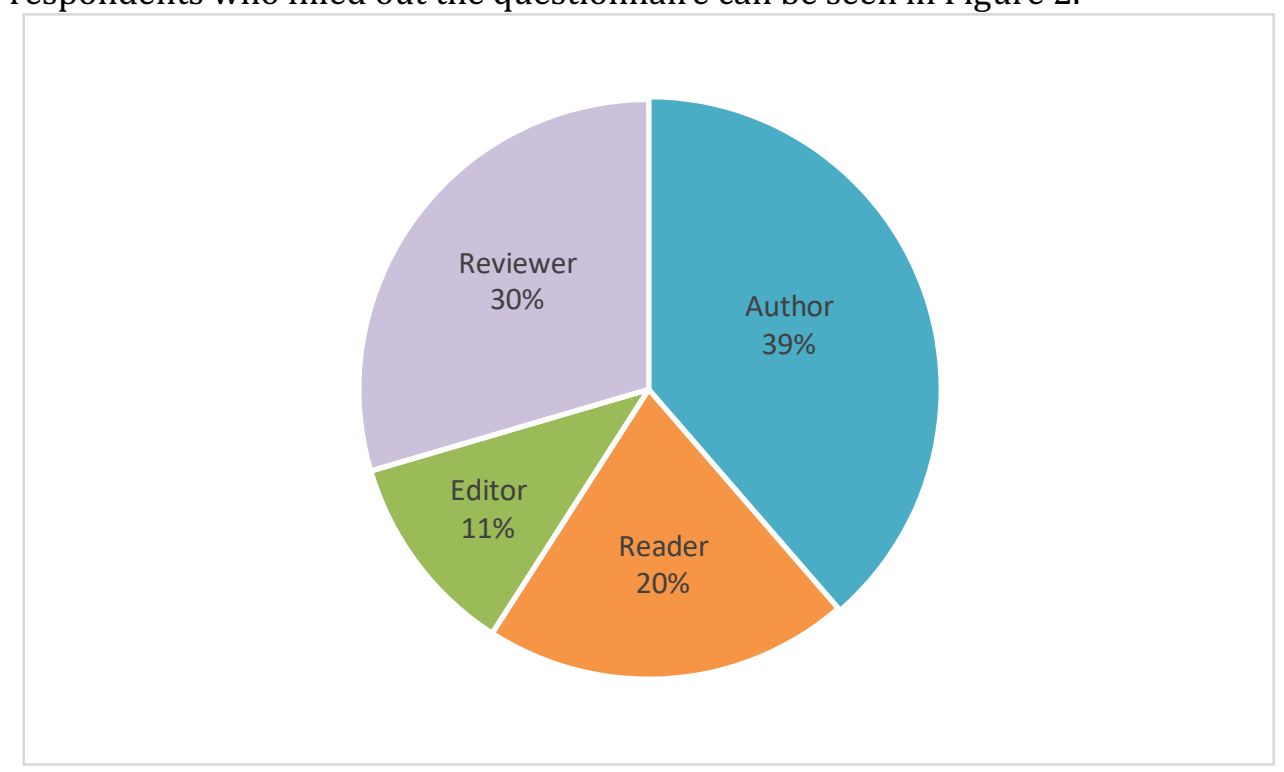

Figure 2 Composition of respondents

After getting the composition for each group of respondents, the next step calculates the SUS value for each group. The results of these calculations are then compared to then analyze the results.

\section{Usability value of each instrument}

The usability value of each instrument is how the respondent responds to the questions for each instrument. There are 10 instruments in SUS, where even and odd questions have different rules in their calculations.

- Q1: I think that I would like to use this system frequently

This instrument describes how respondents will use the OPSI Journal regularly. Based on the results of the questionnaire obtained (Figure 3), it can be seen that for editors, as much as $60 \%$ agreed, while for other groups, most chose to be neutral. It can also be seen that $8 \%$ of reviewers strongly disagree, and $23 \%$ disagree. Meanwhile, for the author, $18 \%$ disagreed, and $11 \%$ of readers also stated the same thing. 


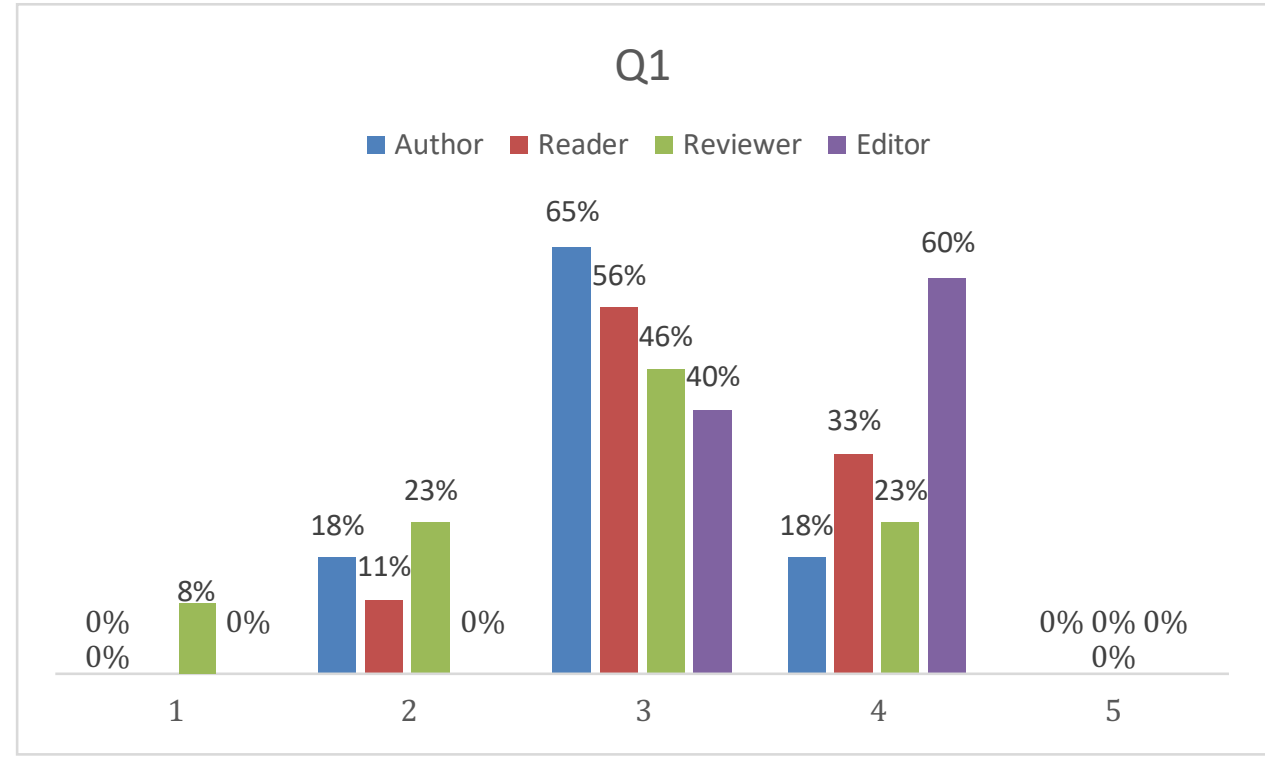

Figure 3 Respondents' opinion on the question Q1

- Q2: I found the system unnecessarily complex

This question is used to determine whether the OPSI Journal system is too complex or not. Based on the study results, what was obtained (figure 4) can be seen that as many as $8 \%$ of reviewers agree that the OPSI journal website is too complex. Meanwhile, the dominant answer in this question is neutral for all groups of respondents. For the category of answers that strongly disagree if the OPSI journal website is too complex, the reader is $33 \%$. This could be because the existing system for readers is easier than other groups.

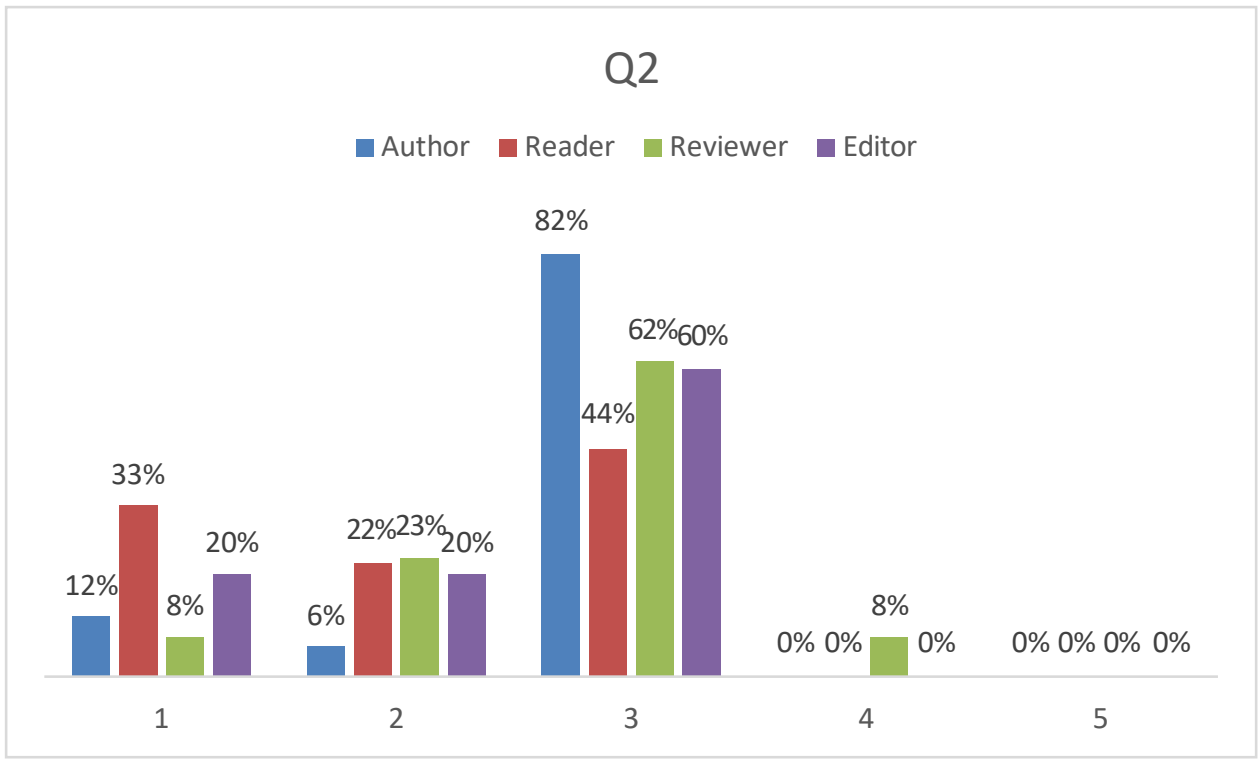

Figure 4 Respondents' opinion on the question Q2

- Q3: I thought the system was easy to use

This instrument is used to measure how easy the OPSI website can be used. Based on the results of the study (Figure 5), it is known that some respondents still answered neutrally. What is of concern is that as many as $6 \%$ of authors and $20 \%$ of editors feel strongly disagree. Meanwhile, a small number of authors, readers, and reviewers also disagree with this instrument. 


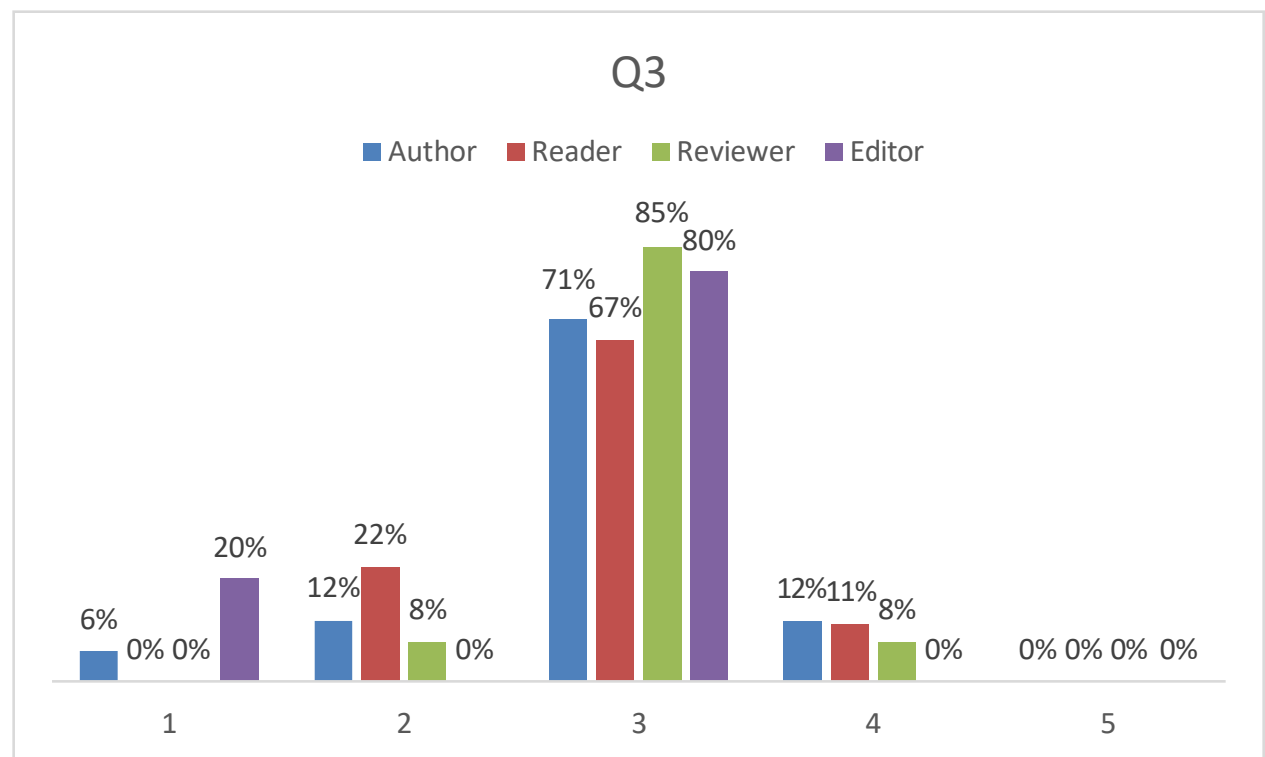

Figure 5 Respondents' opinion on the question Q3

- Q4: I think that I would need the support of a technical person to be able to use this system This instrument asks how respondents need assistance in accessing the OPSI journal. Based on the research results that have been done (Figure 6), the answers to this instrument are more evenly distributed. For reviewers, editors and readers, most of the answers are neutral. Meanwhile, the editors answered disagree and strongly disagree with the same percentage of $40 \%$.

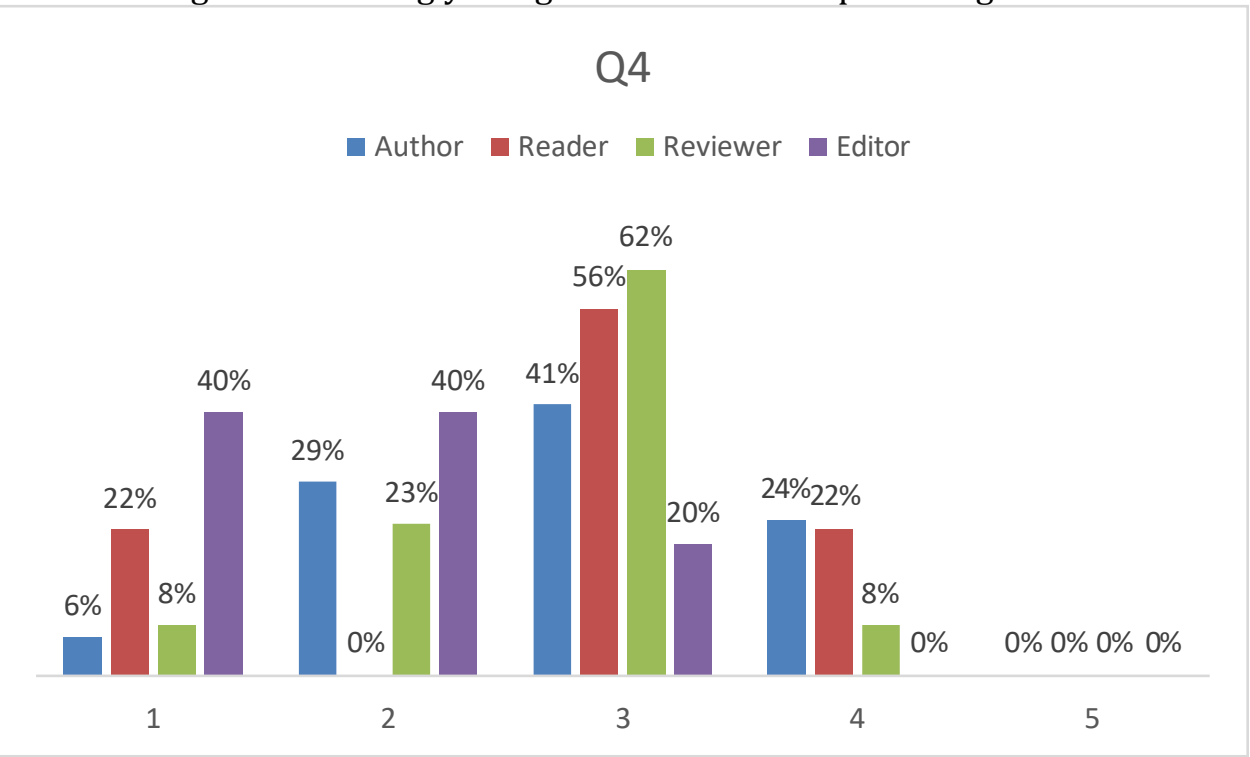

Figure 6 Respondents' opinion on the question Q4

- Q5: I found the various function in this system were well integrated

This instrument asks how the functional conditions in the integrated OPSI journal website are. Based on the results of the research conducted (Figure 7), it can be seen that most of the respondents' answers are dominated by neutral answers. 
RSF Conference Series: Engineering and Technology

Vol 1(1), 378-387

Usability Evaluation of Scientific Journal Websites using the System Usability Scale (Case Study of the OPSI Journal Website)

Sadi, Eko Nursubiyantoro, Yuli Dwi Astanti, Ismianti, Astrid Wahyu Adventri Wibowo, Hasan Mastrisiswadi

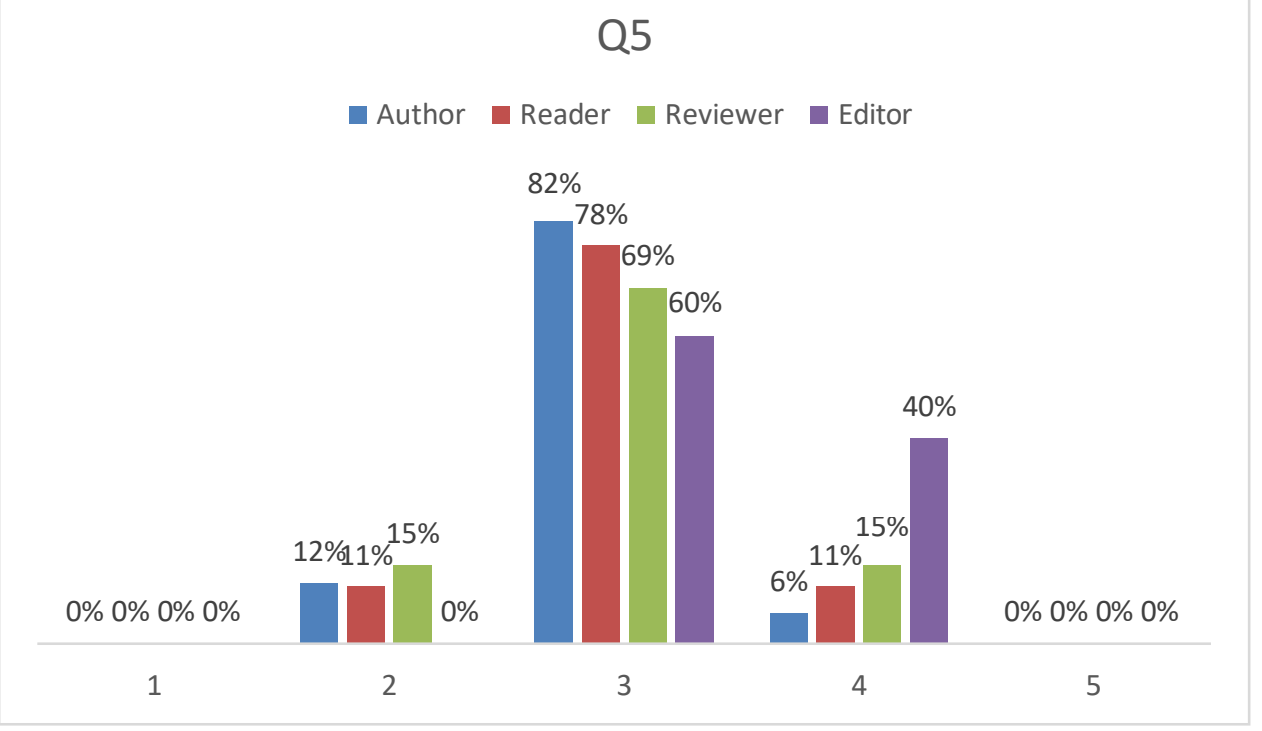

Figure 7 Respondents' opinion on the question Q5

- Q6: I thought there was too much inconsistency inthis system

This instrument explains how many inconsistencies are in the OPSI journal website. Based on the results of the study (Figure 8), it was found that most of the respondents answered neutrally. Meanwhile, $40 \%$ of editors agree with the statement.

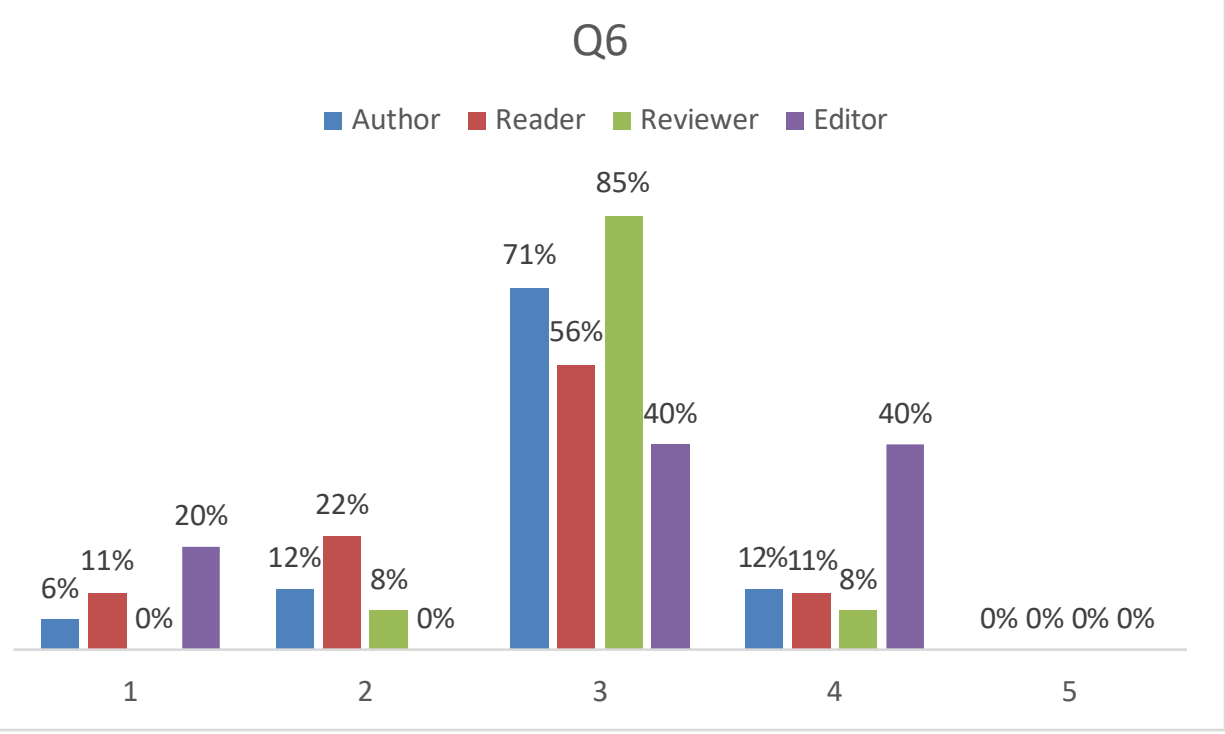

Figure 8 Respondents' opinion on the question Q6

- Q7: I would imagine that most people would learn to use the system very quickly

This instrument is used to determine the level of ease of learning in using the OPSI journal website. Based on the study results (Figure 9), respondents' answers were dominated by neutral answers. In this instrument, only $6 \%$ of the authors agree with this instrument. 


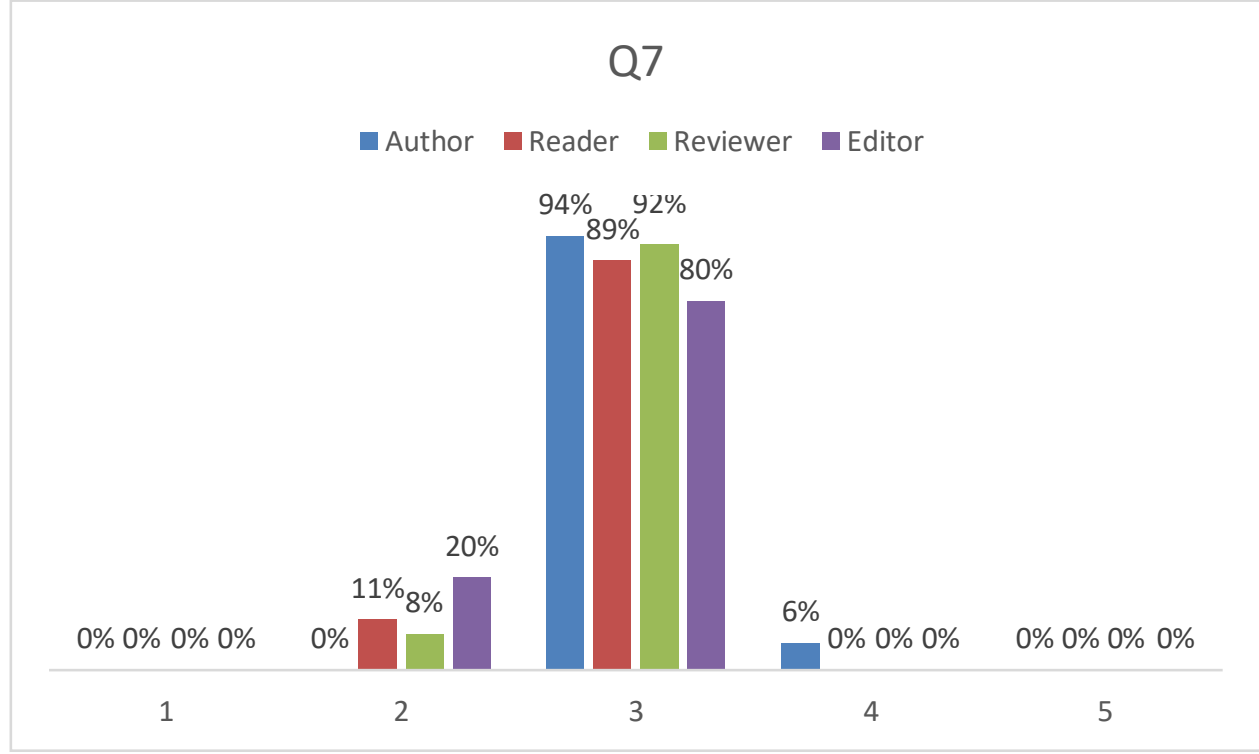

Figure 9 Respondents' opinion on the question Q7

- Q8: I found the system very cumbersome to use

This instrument explains the complexity of the OPSI journal website. The results of the research conducted (Figure 10) obtained results that are almost the same as the previous instrument that most respondents still rate neutral.

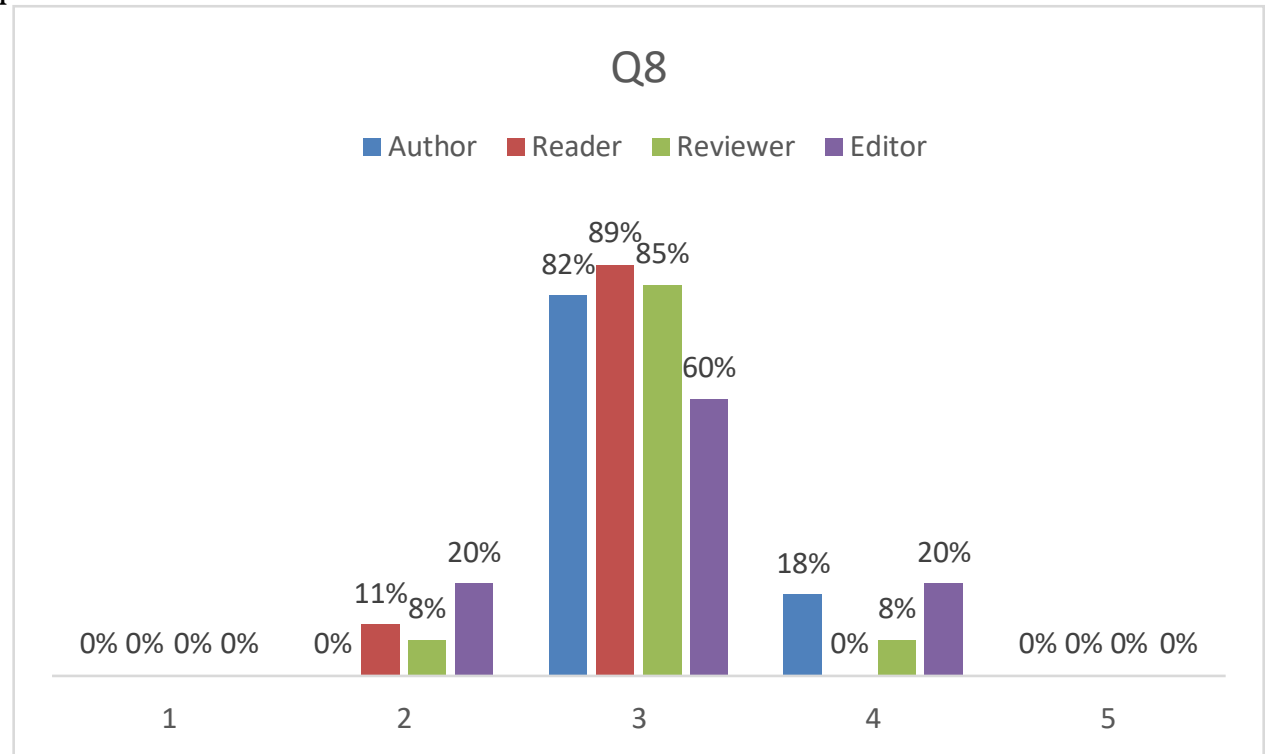

Figure 10 Respondents' opinion on the question Q8

- Q9: I felt very confident using the system

This instrument explains how respondents are confident in using the OPSI journal website. Based on the results of the study (Figure 11), similar results were obtained with the previous instrument, where most of the respondents answered neutrally. However, as many as $6 \%$ of respondents still disagree. 
RSF Conference Series: Engineering and Technology

Vol 1(1), 378-387

Usability Evaluation of Scientific Journal Websites using the System Usability Scale (Case Study of the OPSI Journal Website)

Sadi, Eko Nursubiyantoro, Yuli Dwi Astanti, Ismianti, Astrid Wahyu Adventri Wibowo, Hasan Mastrisiswadi

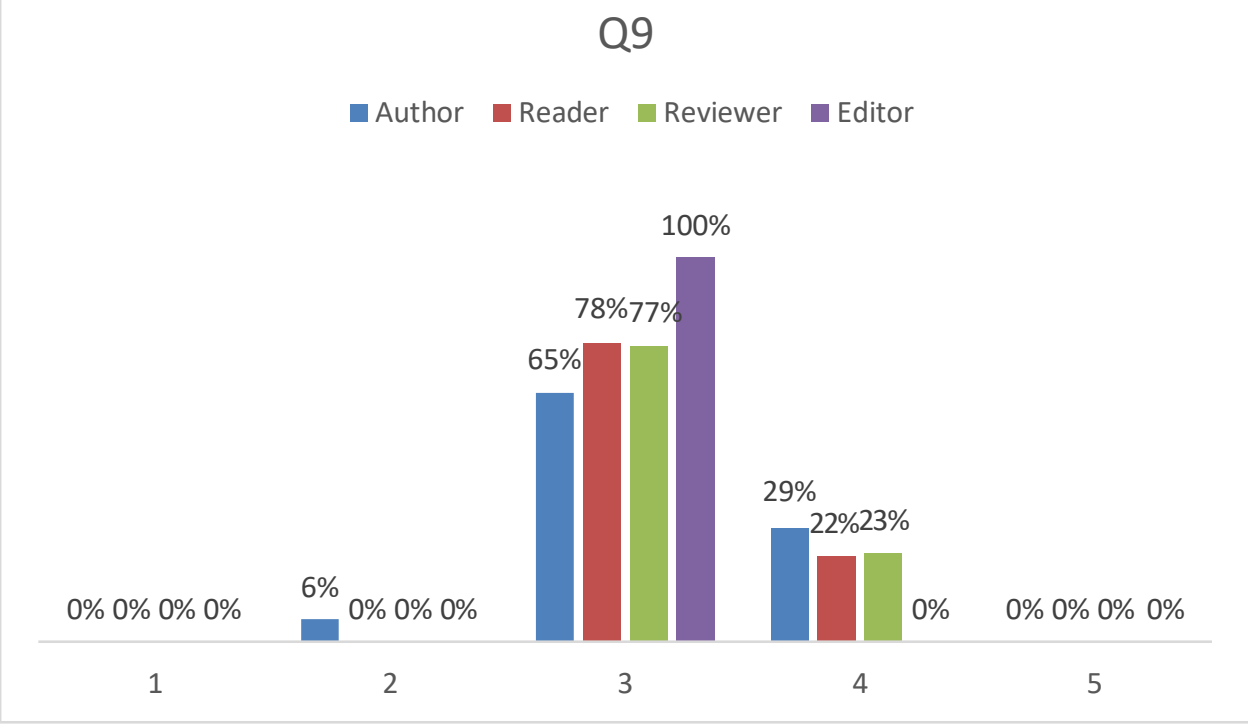

Figure 11 Respondents' opinion on the question Q9

- Q10: I needed to learn a lot of things before I could get going with the system

This instrument explains how respondents need to learn many things first before using the system in the OPSI Journal. Based on the data obtained (Figure 12), it was found that most of the readers $(67 \%)$ felt neutral. Meanwhile, the editor and author both have the same value for the answers to disagree and strongly disagree. Meanwhile, reviewers have the same value for neutral and disagree answers as much as $31 \%$.

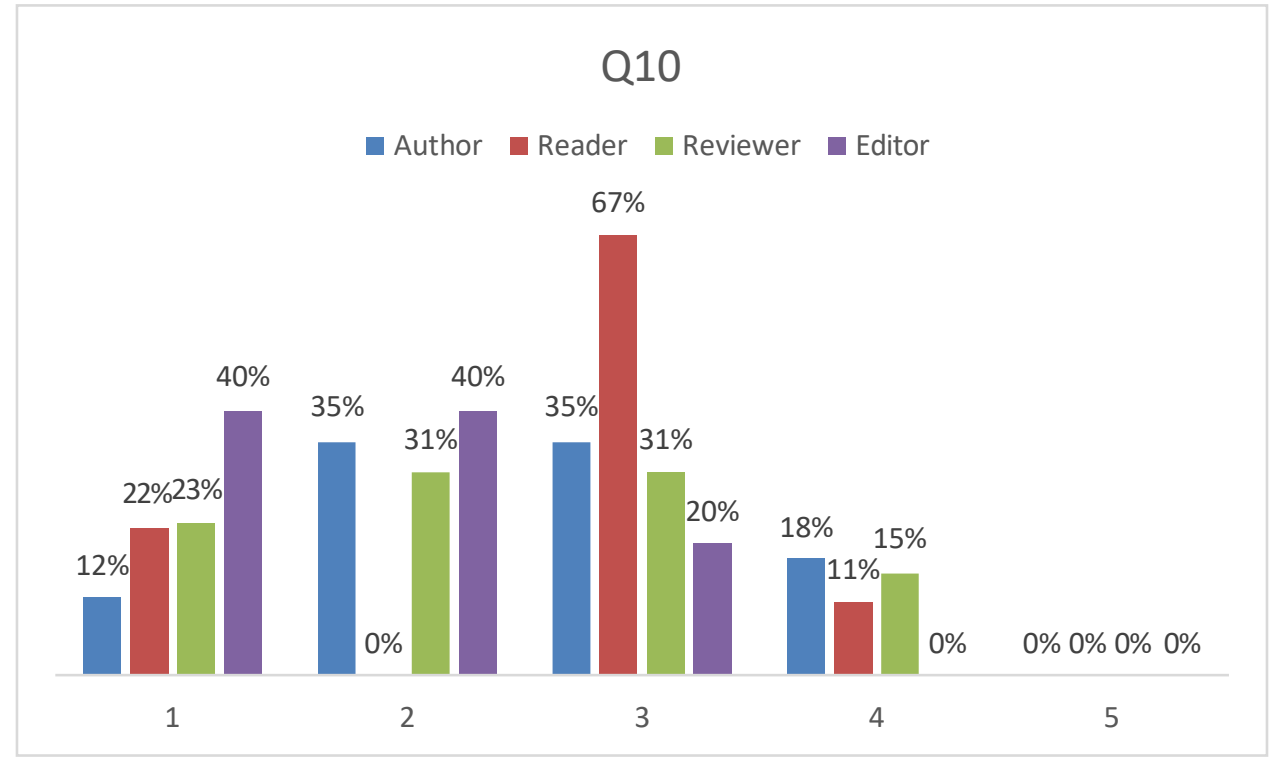

Figure 12 Respondents' opinion on the question Q10

\section{Usability score for OPSI journal website}

The usability value of the OPSI website is calculated using SUS. The usability value will be calculated for each group of respondents. The results of this calculation will later be compared with the overall usability value. The results of the calculations are used to assess whether the usability value of the OPSI website has met the criteria or not. 


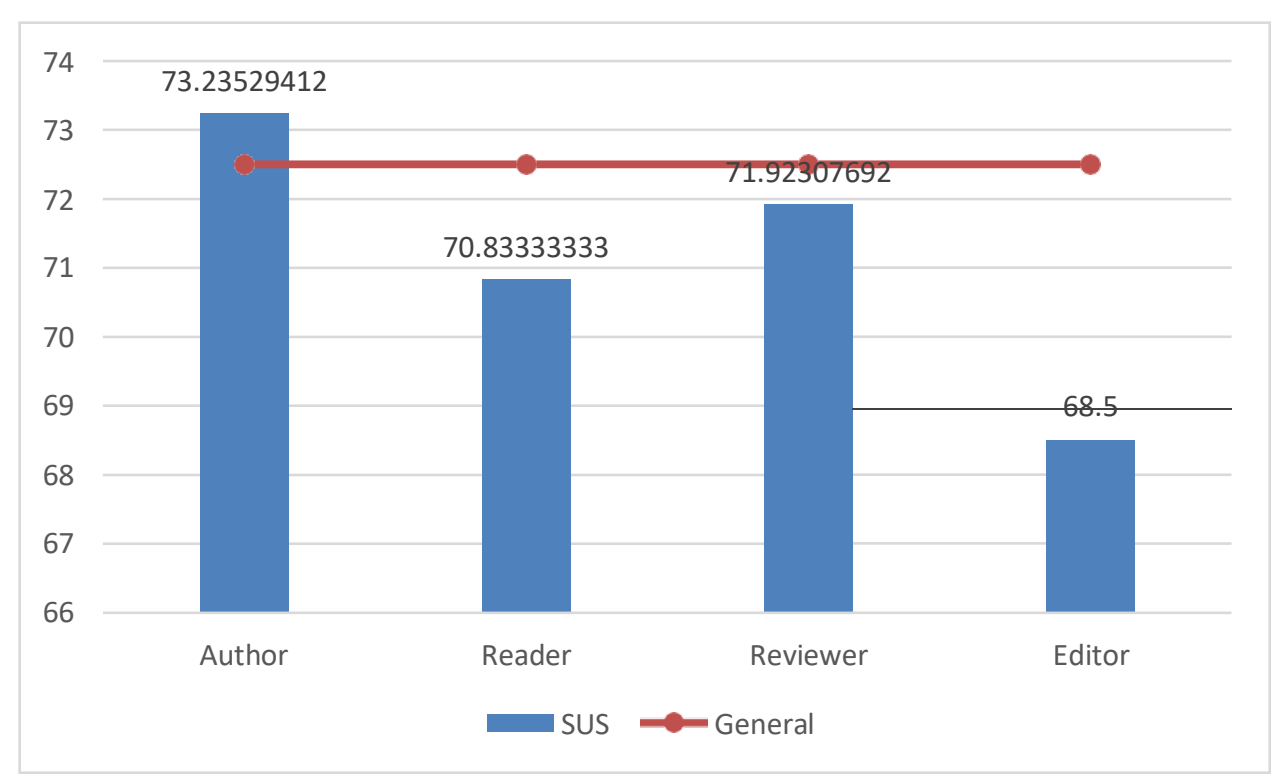

Figure 13 SUS scores for each group of respondents

Based on the data processing that has been carried out, the overall SUS score is 72.5 , which means it has a usability value of category $\mathrm{C}$, or is in a good category, and is still within the acceptable range. The author has a higher SUS score of 73.24, which is still in the same category and range as the overall score. The next highest SUS score is owned by the reviewer group, with a score of 71.92. This value is in the OK category and is in the high marginal position, and is accepted. This position and category are also owned by the reader group with a SUS score of 70.83 .

Meanwhile, the editor has a SUS score of 68.5, in category D, or OK. Even though they are in category D, this group is still in the high marginal range. This may be due to the editor's task being more than the other groups. The editor's task is not only to accept manuscripts but also to arrange reviewers, determine whether a manuscript is accepted or rejected by considering the reviewer's decision, check similarity, and publish.

\section{CONCLUSION AND FURTHER RESEARCH}

Based on the results of the research conducted, it was found that the highest usability value was in the author group, and the lowest was in the editor group. This is because the editor's task is more than that of the other groups. Meanwhile, most respondents still choose to be neutral for each instrument. This could mean that the OPSI Journal website still needs to be improved.

This study only assesses the level of reusability using the SUS method. Many other methods can be used to assess the usability level of the OPSI journal website. In addition, further research is needed from aspects other than usability to improve the quality of the OPSI journal.

\section{Acknowledgement}

The authors acknowledge the support of Lembaga Penelitian dan Pengabdian Masyarakat (LPPM) Universitas Pembangunan Nasional Veteran Yogyakarta.

\section{REFERENCE}

Brooke, J. (1996). SUS -A quick and dirty usability scale Usability and context. Usability Evaluation in Industry.

Brooke, J. (2013). SUS: a retrospective. Journal of Usability Studies.

Departemen Pendidikan Nasional. Undang-undang Republik Indonesia nomor 20 tahun 2003 tentang 
RSF Conference Series: Engineering and Technology

Vol 1(1), 378-387

Usability Evaluation of Scientific Journal Websites using the System Usability Scale (Case Study of the OPSI Journal Website)

Sadi, Eko Nursubiyantoro, Yuli Dwi Astanti, Ismianti, Astrid Wahyu Adventri Wibowo, Hasan Mastrisiswadi sistem pendidikan nasional (2003).

Derisma. (2020). The usability analysis online learning site for supporting computer programming course using System Usability Scale (SUS) in a university. International Journal of Interactive Mobile Technologies. https://doi.org/10.3991/ijim.v14i09.13123

Fathurrahman, F., \& Muhtarom, A. (2019). Pengaruh Pembinaan Tri Dharma Perguruan Tinggi terhadap Perilaku Dosen sebagai Sumber Daya Manusia Pendidikan. Ilmu Pendidikan: Jurnal Kajian Teori Dan Praktik Kependidikan, 4(1), 45-48.

Kaya, A., Ozturk, R., \& Altin Gumussoy, C. (2019). Usability Measurement of Mobile Applications with System Usability Scale (SUS). https://doi.org/10.1007/978-3-030-03317-0_32

Kharis, Santosa, P. I., \& Winarno, W. W. (2019). Evaluasi Usability Pada Sistem Informasi Pasar Kerja Menggunakan System Usablity Scale (SUS). Prosiding Seminar Nasional Sains Dan Teknologi 10 2019.

Lian, B. (2019). Tanggung Jawab Tridharma Perguruan Tinggi Menjawab Kebutuhan Masyarakat. In In Prosiding Seminar Nasional Program Pascasarjana Universitas PGRI Palembang.

Pangestu, A. Y., Safe'i, R., Darmawan, A., \& Kaskoyo, H. (2020). Evaluasi Usability pada Web GIS Pemantauan Kesehatan Hutan Menggunakan Metode System Usability Scale (SUS). MATRIK : Jurnal Manajemen, Teknik Informatika Dan Rekayasa Komputer. https://doi.org/10.30812/matrik.v20i1.709

Ramadhan, D. W. (2019). PENGUJIAN USABILITY WEBSITE TIME EXCELINDO MENGGUNAKAN SYSTEM USABILITY SCALE (SUS) (sTUDI KASUS: WEBSITE TIME EXCELINDO). JIPI (Jurnal Ilmiah Penelitian Dan Pembelajaran Informatika). https://doi.org/10.29100/jipi.v4i2.977

Saputra, A. (2019a). Penerapan Usability pada Aplikasi PENTAS Dengan Menggunakan Metode System Usability Scale (SUS). JTIM : Jurnal Teknologi Informasi Dan Multimedia. https://doi.org/10.35746/jtim.v1i3.50

Saputra, A. (2019b). Penerapan Usability pada Aplikasi PENTAS Dengan Menggunakan Metode System Usability Scale (SUS) (Usability Implementation in PENTAS Application Using the System Usability Scale (SUS) Method). JTIM : Jurnal Teknologi Informasi Dan Multimedia.

Sidik, A. (2018). Penggunaan System Usability Scale (SUS) Sebagai Evaluasi Website Berita Mobile. Technologia: Jurnal Ilmiah. https://doi.org/10.31602/tji.v9i2.1371 